\title{
POTENTIAL OF HALOPHYTES AS CATTLE FODDER: A CASE-STUDY IN PAKISTAN
}

\author{
Haibat Ali ${ }^{1}$, Bilquees Gul ${ }^{1}$, M. Yousuf Adnan' ${ }^{1}$, Muhammad Zaheer Ahmed ${ }^{1}$, Raziuddin Ansari ${ }^{1}{ }^{*}$ \\ and M. Ajmal Khan ${ }^{2}$
}

\author{
${ }^{1}$ Institute of Sustainable Halophyte Utilization, University of Karachi, Karachi-75270, Pakistan; ${ }^{2}$ Qatar Shell \\ Professorial Chair in Sustainable Development, Department of International Affairs, College of Arts and Sciences, \\ Qatar University, Doha, Qatar. \\ *Corresponding author's e-mail: halophyte_razi@yahoo.com
}

\begin{abstract}
Good quality water and arable land are needed to grow conventional crops to provide food for human and animal population. However, burgeoning world population leading to wide spread urbanization and industrialization is aggressively sharing these resources. A solution may be found in using saline water and salinized lands to produce quality animal feed from salt tolerant plants. In this study, two halophytic grasses (Panicum antidotale and Desmostachya bipinnata) were tested for their potential to replace conventional cattle fodder in the diet of cattle. Four trials were conducted in which cow calves were fed diets containing above mentioned halophytes alone or in combination with conventional fodders (wheat and maize). Weight gain in animals fed diets supplemented with halophytes were generally at par with or in few cases marginally better than those on conventional fodder. For instance, $P$. antidotale increased the calf weight around $15 \%$ when used as green and $8 \%$ in case of hay. Feeding Berseem (Trifolium alexandrinum, $15 \%$ crude protein) as the only source of concentrate in a diet containing $D$. bipinnata sustained weight only for about 6-7 weeks after which it started to decrease. Supplementing the diet with a regular concentrate was subsequently needed to restore weight gain. Halophytes as green/hay/concentrate were as good as conventional fodder regarding dressed meat. The protein content of meat was showing increasing trend when replacing conventional fodders with halophytes, particularly $20 \%$ protein was higher in meat when Prosopis juliflora pods and Manilkara zapota were used as concentrate and $P$. antidotale as hay in diet.
\end{abstract}

Keywords: Animal feed, Desmostachya bipinnata, Panicum antidotale, saline resources.

\section{INTRODUCTION}

Shortage of quality feed in Pakistan is a major constraint to the growth of the livestock sector which contributes about $47 \%$ of the agricultural added value (Iqbal and Ahmad, 2005; Allah et al., 2014). The country has vast tracts of salt-affected land which could be used to grow fodder to reduce the feed gap, if nutritious and productive salt-tolerant (halophytic) fodder grasses and shrubs could be identified. Various halophytes are now widely accepted in low rainfall saline regions of Australia, USA and many countries of North Africa and Asia as fodder reserves when other supplies are exhausted (Ahmed and Malik, 2002; Al-Ahmadi and Kafi, 2008; ElShaer, 2010). A survey of the halophytic flora established the presence of a number of such species on the Sindh and Baluchistan coast of Pakistan which have similar potential (Khan and Qaiser, 2006). However information about the agronomy and feed value of most of these and other native halophytes which could be measured in terms of animal product outputs is largely lacking (Norman et al., 2013). Experiments were hence conducted wherein two perennial halophytic grasses [Panicum antidotale and Desmostachya bipinnata] were fed to cattle in four independent trials in various combinations with conventional fodders (wheat and maize). Selection of these species was based on their high crude protein, low ash content compared to other halophytic shrubs of this area as well as high yield and availability throughout the year. The potential use of some halophytic ingredients (Prosopis juliflora pods and Sapodila-Manilkara zapota fruits) as low-cost supplement to conventional energy ration was also explored in one of these trials.

Panicum antidotale (formerly identified as Panicum turgidum) is a salt excluder distributed in salt affected areas and deserts from Morocco to India. The plants may attain a height of 1 meter in $25-30$ days in summer $\left(30-35^{\circ} \mathrm{C}\right)$ but the growth slows down in winter (Khan et al., 2009). It is reported as a fairly high salt tolerant plant with optimal growth at 125 $\mathrm{mM} \mathrm{NaCl}$ (Koyro et al., 2013). D. bipinnata is also a perennial having erect culms 50-100 cm long, widely distributed in North Africa, Asia, Saudi Arabia, Pakistan, Indo-China and Malaysia (Cope, 1982). It is moderately salt tolerant at germination and may grow in salinity of up to 100 $\mathrm{mM} \mathrm{NaCl}$ without any drastic decrease in yield (Gulzar et al., 2007).

This study which aimed at exploring the suitability of local halophytes as component of animal feed, was conducted with 
the following objectives: 1) Compare cattle growth when replacing the conventional green component of diet with $P$. antidotale, 2) Compare cattle growth when replacing the conventional hay component of diet with D. bipinnata hay, 3) Compare cattle growth when replacing the conventional hay component of diet with $P$. antidotale hay, and 4) Compare cattle growth when replacing the traditional concentrate sources (cotton seed cake) of diet with halophytic shrubs (Prosopis juliflora pods and Manilkara zapota fruit), both in the presence and absence of $P$. antidotale hay.

\section{MATERIALS AND METHODS}

Four trials were conducted using cow calves which were fed diets containing halophytic grasses and shrubs alone or in combination with conventional (non-halophytic) components. Experimental details of these trials and composition of diets are shown in Tables 1 and 2.

Animals and their management: Calves of uniform weight and size were obtained from the local market, distributed in groups of four and vaccinated/drenched before each experiment to guard against internal and external diseases and worms. Subsequently, regular checkups were conducted by a veterinarian. The calves were housed in a thatched roof shed with feeding pans and provided specific diet formulations (Table 2) twice daily at 8-AM and 4-PM. An open fenced area was available to the animals to roam and rest between the meals. Drinking water was also available in this area. The animals were weighed on an electric balance at weekly intervals before the morning feed.

Fodder sources: Panicum antidotale was grown at the experimental site and irrigated with brackish water, while $D$. bipinnata was harvested from natural populations existing under saline soils in and around the experimental site. $P$. juliflora pods and $M$. zapota fruits used to supplement the concentrate were obtained from trees growing on the farm. The other fodders i.e. dry wheat straw and green maize (Zea mays) and berseem (Trifolium alexandrinum) were procured from local market. The chemical composition of these fodders is shown in Table 3. The dry and green fodder were chopped and mixed before offering to animals.

Laboratory analyses: Analyses of feed ingredients (Ash, Crude Protein, Crude Fiber and Total Oxalates) were carried out according to AOAC (2005). Neutral Detergent Fiber (NDF), Acid Detergent Fiber (ADF), lignin, cellulose and hemi-cellulose were determined .

Table 2. Composition of diets used in the trials (Diet composition in $\mathrm{g} / \mathrm{kg} \mathrm{DM})$.

Table 1.Summary of trials comparing the potential of fresh and dry fodder of two perennial halophytic grasses (Panicum antidotale and Desmostachya bipinnata) and pods and fruit of two halophytic shrubs (Prosopis juliflora and Manilkara zapota) as cattle feed.

\begin{tabular}{|c|c|c|c|c|}
\hline \multicolumn{5}{|c|}{ Trials } \\
\hline & 1 & 2 & 3 & 4 \\
\hline Objective & $\begin{array}{l}\text { Compare growth and } \\
\text { carcass characteristics of } \\
\text { cow-calves fed fresh } \\
\text { maize and } P \text {. antidotale } \\
\text { based diets }\end{array}$ & $\begin{array}{l}\text { Compare growth and } \\
\text { carcass characteristics } \\
\text { of cow-calves fed } \\
\text { wheat straw and } D \text {. } \\
\text { bipinnata hay based } \\
\text { diets }\end{array}$ & $\begin{array}{l}\text { Compare growth and } \\
\text { carcass characteristics } \\
\text { of cow-calves fed } \\
\text { wheat straw and } P \text {. } \\
\text { antidotale hay based } \\
\text { diets }\end{array}$ & $\begin{array}{l}\text { Compare growth and carcass } \\
\text { characteristics of cow-calves } \\
\text { fed wheat straw and } P \text {. } \\
\text { antidotale hay based diets } \\
\text { supplemented with either } \\
\text { traditional (cotton seed cake) or } \\
\text { halophytic shrub (Prosopis } \\
\text { juliflora pods and Manilkara } \\
\text { zapota fruit) based concentrates }\end{array}$ \\
\hline Location & $\begin{array}{l}\text { Zia Model Farm, Hub } \\
\text { Kund, } \\
\text { Balochistan, Pakistan }\end{array}$ & $\begin{array}{l}\text { Zia Research Center, } \\
\text { Gadap } \\
\text { Town, Karachi }\end{array}$ & $\begin{array}{l}\text { Zia Research Center, } \\
\text { Gadap } \\
\text { Town, Karachi }\end{array}$ & $\begin{array}{l}\text { Zia Research Center, Gadap } \\
\text { Town, Karachi }\end{array}$ \\
\hline Diet & 1. Fresh maize & 1. Wheat straw & 1. Wheat straw & 1. Traditional concentrate \\
\hline comparison & 2. Fresh $P$. antidotale & 2. D. bipinnata hay & 2. P. antidotale hay & 2. Halophyte-concentrate \\
\hline $\begin{array}{l}\text { Animals/ } \\
\text { Treatment }\end{array}$ & 4 growing male calves & 4 growing male calves & 4 growing male calves & 4 growing male calves \\
\hline Age & $10-12$ months & $10-12$ months & $10-12$ months & 10-12 months \\
\hline Initial weight & $135 \mathrm{~kg}$ & $130 \mathrm{~kg}$ & $135 \mathrm{~kg}$ & $135 \mathrm{~kg}$ \\
\hline Duration & 14 week & 14 week & 12 week & 12 week \\
\hline $\begin{array}{l}\text { Feeding } \\
\text { management }\end{array}$ & $\begin{array}{l}\text { Diet was offered twice } \\
\text { daily at } 4 \mathrm{~kg} / \mathrm{head} \text { from } \\
\text { week } 1-7 \text {, and } 5 \mathrm{~kg} / \mathrm{head} \\
\text { from week } 8-14 .\end{array}$ & $\begin{array}{l}\text { Diet was offered twice } \\
\text { daily at } 4.5 \mathrm{~kg} / \mathrm{head} \\
\text { throughout the trail. }\end{array}$ & $\begin{array}{l}\text { Diet was offered twice } \\
\text { daily at } 5 \mathrm{~kg} / \text { head } \\
\text { throughout the study } \\
\text { period. }\end{array}$ & $\begin{array}{l}\text { Diet was offered twice daily at } 5 \\
\mathrm{~kg} / \text { head throughout the study } \\
\text { period. }\end{array}$ \\
\hline
\end{tabular}




\begin{tabular}{|c|c|c|c|c|c|c|}
\hline \multirow{2}{*}{\multicolumn{2}{|c|}{ Tria }} & \multicolumn{5}{|c|}{ Diets } \\
\hline & & 1 & 2 & 3 & 4 & 5 \\
\hline \multirow[t]{5}{*}{1} & Wheat straw & 420 & 420 & 420 & 420 & -- \\
\hline & Fresh maize fodder & 420 & 250 & 160 & 0 & -- \\
\hline & Fresh Panicum antidotale & 0 & 0 & 90 & 250 & -- \\
\hline & Wheat bran & 160 & 160 & 160 & 160 & -- \\
\hline & Concentrate $^{\mathrm{a}}$ & 0 & 160 & 160 & 160 & -- \\
\hline \multirow[t]{4}{*}{2} & Fresh barseem & 250 & 250 & 250 & 250 & 250 \\
\hline & Wheat straw & 750 & 550 & 375 & 200 & 0 \\
\hline & Desmostachya bipir & 0 & 200 & 375 & 550 & 750 \\
\hline & Concentrate $^{\mathrm{a}}$ & 0 & 0 & 0 & 0 & 0 \\
\hline \multirow[t]{4}{*}{3} & Fresh maize fodder & 450 & 450 & 450 & 450 & 450 \\
\hline & Wheat straw & 450 & 300 & 225 & 150 & 0 \\
\hline & Panicum antidotale hay & 0 & 150 & 225 & 300 & 450 \\
\hline & Concentrate $^{\mathrm{b}}$ & 100 & 100 & 100 & 100 & 100 \\
\hline \multirow[t]{5}{*}{4} & Fresh maize & 450 & 450 & 450 & 450 & -- \\
\hline & Wheat straw & 450 & 0 & 450 & 0 & -- \\
\hline & Panicum antidotale hay & 0 & 450 & 0 & 450 & -- \\
\hline & Concentrate $^{\mathrm{b}}$ & 100 & 100 & 0 & 0 & -- \\
\hline & Concentrate $^{\mathrm{c}}$ & 0 & 0 & 100 & 100 & \\
\hline
\end{tabular}

Concentrate a (cotton seed cake 25\%, Wheat bran 20\%, Sun flower seed 20\%, Rice polish 15\%, Molasses 10\%, Quick lime 7\%, and Dicalcium phosphate 3\%). Concentrate ${ }^{\mathbf{b}}$ (Maize seed 10\%, Maize seed cake $20 \%$, rice polish $30 \%$, Cotton seed cake $10 \%$, Turi cake $5 \%$, Wheat bran $17 \%$, Molasses 5\%, DCP $1 \%$, Lime $1 \%$, Salt $0.5 \%$, and Urea $0.5 \%$ ). Concentrate ${ }^{\mathbf{c}}$ (Maize seed $10 \%$, Maize seed cake $20 \%$, rice polish $30 \%$, Propis juliflora pods $10 \%$, Turi cake 5\%, Wheat bran 17\%, Manilkara zapota 5\%, DCP 1\%, Lime 1\%, Salt $0.5 \%$, and Urea $0.5 \%$ ).

Carcass characteristics: At the end of experiment, calves were weighed and slaughtered in a slaughter house. Carcass was weighed and carried in chilled vehicles to the storage unit where further observations were done.

Statistical analyses: Data were analyzed using SPSS version 11.0 (SPSS, 2001). Mean and standard error was calculated to show the difference between individual treatments. Regression analyses were used to show the relationship in live weight with time.

\section{RESULTS}

Replacing maize green fodder with P. antidotale: A linear increase in the live weight of animals was observed during the course of experiment (Fig. 1A, Table 4-Trial 1). Animals fed diet 2 gained the highest weight (43\% of initial) followed by those fed diets 3 and 4 (no differences) but all these three were significantly superior to diet 1 (please refer to Table 2 for diet components). The weight gain at slaughter calculated as percent of initial or on the basis of weight gain per week shows almost 2-folds increase in weight of animals fed diets 2, 3, 4 compared to diet 1 (Table 4-Trial 1). Dressed meat was around $50 \%$ in these three treatments compared to about $46 \%$ in case of diet 1 . The weight of one hind or one fore leg was about $1.5 \mathrm{~kg}$ more in animals fed diet 2, 3, 4 than from those fed diet 1 . Visual observations and abdominal fat indicated that meat from animals fed diet 4 (consist of $100 \% P$. antidotale) was more lean and hence better for human consumption, compared to that from animals consuming other diets while there was no difference in taste of meat between the diets. Protein content of meat was marginally higher when $P$. antidotale was used in place of maize green fodder (Table 4-Trial 1).

Replacing dry wheat straw with dry D. bipinnata: This experiment was conducted to test the efficacy of $D$. bipinnata as a suitable alternative to wheat straw as a dry fodder while using green berseem (T. alexandrinum having $15 \%$ protein), a legume as a uniform source (25\% of total diet) of green fodder. The animals maintained or gained weight slightly in the absence of energy ration while in case of those animals fed solely D. bipinnata (Fig. 1B, Table 4-Trial 2), there was a weight loss initially however, animals started gaining weight faster after adding the energy ration in diet (please refer to Table 2 for diet components). Observations recorded at the

Table 3. Chemical composition, energy content and digestibility of two perennial halophytic and three conventional fodders in Pakistan (Khan et al., unpublished data).

\begin{tabular}{lccccc}
\hline Chemical constituents (\%) & $\begin{array}{c}\text { Panicum } \\
\text { antidotale }\end{array}$ & $\begin{array}{c}\text { Desmostachya } \\
\text { bipinnata }\end{array}$ & $\begin{array}{c}\text { Wheat } \\
\text { Straw }\end{array}$ & Maize & Berseem \\
\hline Moisture content & 38.00 & 34.00 & 10.00 & 25.00 & 11.00 \\
Ash content & 11.00 & 14.00 & 08.50 & 07.00 & 11.20 \\
Crude protein (CP) & 18.87 & 10.20 & 05.00 & 11.00 & 15.32 \\
Crude fiber (CF) & 21.30 & 45.20 & 35.00 & 25.00 & 29.82 \\
Acid detergent fiber (ADF) & 31.66 & 39.00 & 57.00 & 29.00 & 38.31 \\
Neutral detergent fiber (NDF) & 59.50 & 63.00 & 81.00 & 48.00 & 54.92 \\
Lignin & 06.30 & 06.60 & 17.00 & 24.00 & 12.27 \\
Cellulose & 27.66 & 26.00 & 33.70 & 41.00 & 26.40 \\
Hemicellulose & 27.84 & 24.00 & 25.00 & 36.00 & 16.61 \\
Total oxalate & 03.06 & 02.06 & - & - & - \\
\hline
\end{tabular}


Table 4. Observations recorded at the termination of trial (Mean \pm Standard Error).

\begin{tabular}{|c|c|c|c|c|c|}
\hline \multirow[t]{2}{*}{ Observations } & \multicolumn{5}{|c|}{ Diets* } \\
\hline & 1 & 2 & 3 & 4 & 5 \\
\hline \multicolumn{6}{|l|}{ Trial \# 1} \\
\hline Weight gain from initial (\%) & $23 \pm 5$ & $43 \pm 3$ & $37 \pm 3$ & $38.0 \pm 3$ & - \\
\hline Weight gain per week $(\mathrm{kg})$ & $1.94 \pm 1$ & $3.75 \pm 1$ & $3.31 \pm 0$ & $3.38 \pm 1$ & - \\
\hline Carcass weight (kg/animal) & $75.2 \pm 3$ & $96.1 \pm 2$ & $93.6 \pm 4$ & $91.2 \pm 2$ & - \\
\hline Dressed meat (\%) & $45.9 \pm 3$ & $49.7 \pm 3$ & $49.0 \pm 2$ & $47.6 \pm 1$ & - \\
\hline Protein in meat (\%) & $65.4 \pm 4$ & $64.4 \pm 6$ & $72.9 \pm 4$ & $70.3 \pm 3$ & - \\
\hline Fat in meat $(\%)$ & $25.2 \pm 1$ & $28.2 \pm 1$ & $25.1 \pm 2$ & $24.9 \pm 1$ & - \\
\hline Weight of one hind leg (kg) & $11.1 \pm 1$ & $12.5 \pm 0$ & $12.7 \pm 1$ & $12.4 \pm 1$ & - \\
\hline Weight of one fore leg $(\mathrm{kg})$ & $5.3 \pm 0$ & $6.6 \pm 1$ & $6.5 \pm 1$ & $6.2 \pm 0$ & - \\
\hline \multicolumn{6}{|l|}{ Trial \# 2} \\
\hline Weight gain from initial (\%) & $16.0 \pm 1$ & $12.3 \pm 1$ & $9.1 \pm 0$ & $10.0 \pm 0$ & $-2.0 \pm 1$ \\
\hline Weight gain per week (kg) & $1.23 \pm 0$ & $0.94 \pm 0$ & $0.61 \pm 0$ & $0.67 \pm 1$ & $-0.15 \pm 0$ \\
\hline Carcass weight (kg/animal) & $59.5 \pm 2$ & $50.0 \pm 2$ & $64.2 \pm 1$ & $63.4 \pm 0$ & $61.9 \pm 1$ \\
\hline Dressed meat $(\%)$ & $40.64 \pm 5$ & $38.75 \pm 6$ & $44.04 \pm 5$ & $46.07 \pm 5$ & $46.8 \pm 1$ \\
\hline Protein in meat $(\%)$ & $62.98 \pm 5$ & $65.24 \pm 3$ & $71.68 \pm 7$ & $74.98 \pm 5$ & $73.24 \pm 8$ \\
\hline Fat in meat $(\%)$ & $25.6 \pm 3$ & $27.4 \pm 3$ & $21.9 \pm 1$ & $17.56 \pm 0$ & $18.2 \pm 1$ \\
\hline Weight of one hind leg (kg) & $10.98 \pm 1$ & $8.88 \pm 1$ & $12.30 \pm 0$ & $11.70 \pm 2$ & $11.35 \pm 2$ \\
\hline Weight of one fore leg $(\mathrm{kg})$ & $4.72 \pm 0$ & $3.67 \pm 0$ & $5.2 \pm 0$ & $4.9 \pm 0$ & $4.6 \pm 0$ \\
\hline \multicolumn{6}{|l|}{ Trial \# 3} \\
\hline Weight gain from initial (\%) & $40.0 \pm 1$ & $48 \pm 1$ & $35.4 \pm 1$ & $34.2 \pm 1$ & $31.0 \pm 0$ \\
\hline Weight gain per week $(\mathrm{kg})$ & $3.6 \pm 0$ & $4.4 \pm 0$ & $3.2 \pm 0$ & $3.1 \pm 0$ & $2.8 \pm 0$ \\
\hline Carcass weight (kg/animal) & $82.4 \pm 2$ & $84.3 \pm 2$ & $83.3 \pm 2$ & $82.4 \pm 2$ & $78.7 \pm 2$ \\
\hline Dressed meat (\%) & $50.0 \pm 2$ & $48.3 \pm 2$ & $50.6 \pm 1$ & $50.2 \pm 1$ & $49.2 \pm 0$ \\
\hline Protein in meat $(\%)$ & $62.4 \pm 3$ & $68.4 \pm 2$ & $72.9 \pm 2$ & $70.3 \pm 4$ & $73.4 \pm 4$ \\
\hline Fat in meat $(\%)$ & $28.8 \pm 1$ & $28.2 \pm 1$ & $26.0 \pm 0$ & $24.9 \pm 1$ & $24.6 \pm 0$ \\
\hline Weight of one hind leg (kg) & $12.3 \pm 0$ & $12.5 \pm 1$ & $13.8 \pm 1$ & $13.4 \pm 1$ & $14.1 \pm 0$ \\
\hline Weight of one fore leg $(\mathrm{kg})$ & $6.3 \pm 0$ & $7.5 \pm 0$ & $7.8 \pm 0$ & $7.4 \pm 0$ & $8.3 \pm 0$ \\
\hline \multicolumn{6}{|l|}{ Trial \# 4} \\
\hline Weight gain from initial (\%) & $40.6 \pm 3$ & $31.0 \pm 2$ & $38.0 \pm 1$ & $44.0 \pm 1$ & - \\
\hline Weight gain per week (kg) & $3.7 \pm 0$ & $2.8 \pm 0$ & $3.5 \pm 0$ & $4.0 \pm 0$ & - \\
\hline Carcass weight (kg/animal) & $82.4 \pm 3$ & $78.7 \pm 7$ & $84.6 \pm 5$ & $88.3 \pm 3$ & -- \\
\hline Dressed meat (\%) & $50.0 \pm 1$ & $49.2 \pm 1$ & $50.0 \pm 0$ & $50.0 \pm 1$ & - \\
\hline Protein in meat $(\%)$ & $52.4 \pm 2$ & $62.8 \pm 2$ & $72.9 \pm 2$ & $74.43 \pm 2$ & - \\
\hline Fat in meat $(\%)$ & $21.9 \pm 1$ & $18.2 \pm 0$ & $25.9 \pm 1$ & $17.9 \pm 1$ & - \\
\hline Weight of one hind leg (kg) & $12.3 \pm 0$ & $14.1 \pm 0$ & $13.7 \pm 1$ & $14.4 \pm 1$ & - \\
\hline Weight of one fore leg $(\mathrm{kg})$ & $6.3 \pm 0$ & $8.3 \pm 1$ & $7.1 \pm 0$ & $8.6 \pm 0$ & - \\
\hline
\end{tabular}

${ }^{*}$ See Table 2 for diet components.

termination of trial (Table 4-Trial 2) shows nominal weight gain with less than $50 \%$ dressed meat yield in all the treatments. The use of dry D. bipinnata in the replacement of dry wheat straw increased protein content up to $12 \%$, while decreasing fat around $8 \%$ in meat (Table 4-Trial 2).

Replacing dry wheat straw with P. antidotale hay: There was steady increase in live weight of animals under all diets (Fig. 1C, Table 4-Trial 3) but this increase was $~ 10 \%$ less in the animals fed on total $P$. antidotale hay (diet 5, Table 2), while $P$. antidotale up to $50 \%$ of wheat straw (diet 2, Table 2) did not seem to have any adverse effect on live weight of animals. The presence of $P$. antidotale in diet as hay increased the protein content around $11 \%$ while no effect was observed in dressed meat.

Supplementing concentrate partially with halophytic constituents: A gradual increase in live weight of animals was observed in all treatments but the animals feeding on the diet containing halophytic concentrate either with wheat straw or P. antidotale hay, appeared to be better than others (Fig. 1D, Table 4-Trial 4). These treatments were also better in terms of high protein $(22 \%)$ and low fat in meat. Dressing (\%) however, was not affected by any of the treatments and was around $50 \%$ in all the cases. 


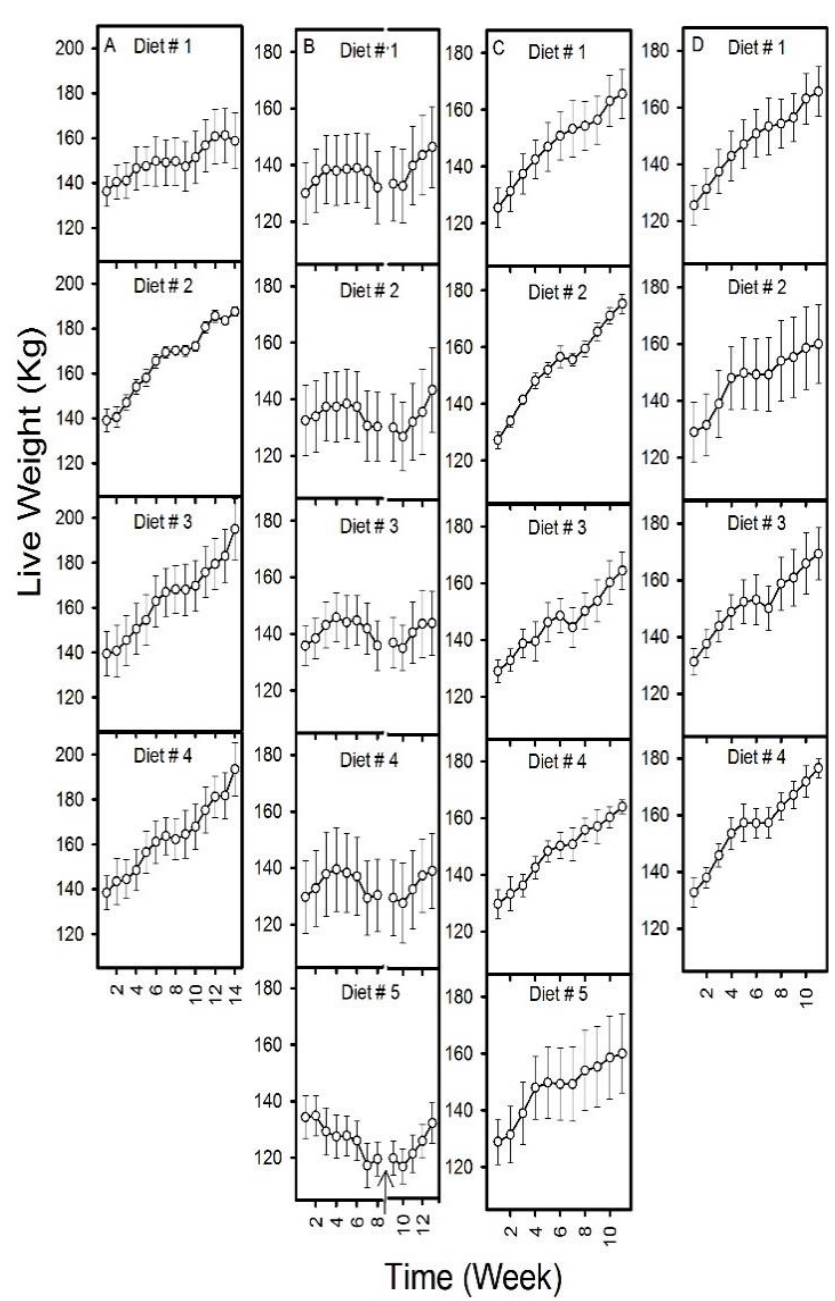

Figure 1.Change in the weight of animal during experiment: A) Trial \# 1; B) Trial \# 2; C) Trial \# 3 and D) Trial \# 4. Arrow in Trial \# 2 shows the time when concentrate was added in the diet because animal was losing their weight very quickly. (Please refer to table 2 for diet components).

\section{DISCUSSION}

The benefits of proper diet for the animals and the losses that may accrue due to malnourishment need no emphasis. Deficient nutrition produces weak animals which are prone to diseases hence, proper management of the flock is necessary for optimum production. It has been suggested that livestock development is predominantly a matter of nutrition but the ground realities in this context present a very bleak picture in many developing countries; for instance, $70 \%$ animals remain mal- or under-nourished in Pakistan (Khan, 2011). The price of fodder fluctuates depending on supply which the resourcepoor owners of animals find difficult to cope with effectively. The problems addressed in this study are finding alternate sources of dry and green fodder and suitable low cost energy ration to make cattle rearing profitable. In this study we are getting initial success in identifying some halophytic plant species with potential as dry and/or green fodder as well as the use of some halophytic resources as energy ration components.

$P$. antidotale appears promising, which was tested as a substitute for maize (Trial 1) but it may also be used as hay after drying (Trial 3, 4). P. antidotale fulfilled the animal requirement related to minerals and fibers when used as green or dry hay. It is a perennial and can continually be harvested (for $~ 30-35$ times) without reseeding thus saving considerable time and resources. $P$. antidotale has good nutritional value with higher yield when irrigated with brackish water (10-15 $\mathrm{dS} / \mathrm{m}$ ). In addition, the use of proper fertilizers (NPK 120 $\mathrm{Kg} / \mathrm{ha}$ ) and organic manures increased its yield and improved its nutritional property by lowering the salt contents and harmful secondary metabolites) (Ali et al., 2014). The present trials on growth of $P$. antidotale are being conducted mainly in coastal Pakistan (Baluchistan province) where it is found growing naturally and is well adapted to those conditions. For new areas, we recommend initial experimental production and management practices of this grass before full scale cultivation because its salt tolerance may vary depending on the location where other ecological factors may also come into play.

Our studies have also identified D. bipinnata, another grass of the wastelands as a source of dry fodder and studies have shown it to be a good substitute for wheat straw (Trial 2). It is also a perennial like $P$. antidotale and colonizes saline lands with shallow water tables. Young plants of D. bipinnata are grazed but older ones with hard fiber injure the mouth of the animals however, when used after shredding and drying, it proved to be good hay. The decrease in weight of animals observed in trial 2 appeared to be more a consequence of inadequate concentrate in the feed rather than any harmful effect of $D$. bipinnata. The yield maximization and other agronomic trials have not been conducted but the natural growth of the grass indicates good potential yield. Its production technology, nutrition level, and palatability are subject of a separate study.

There is a general consensus among animal nutritionists that $8-10 \%$ ash in feed is a safe limit for animals (Badri and Hamed, 2000). P. antidotale, with $11 \%$ ash (Table 3) may be just about right in this regard. The other grass of the study- $D$. bipinnata, with a bit higher ash (14\%, Table 3), exceeds this limit and hence needs cautious approach. Identification of halophytes having low salt in foliage will help in direct feeding and may serve as a replacement of traditional green fodder. In case of 'accumulators', chopping of plant leaves into small portions and washing with water (even with brackish water where foliage salt contents are higher) has been reported to reduce internal salt (Le Houerou, 1992). Subsequent drying removes many of the undesirable volatile components (Lieth and Masoom, 1993). The utilization of 
less palatable and less nutritious species as silage is worth exploring (Khan unpublished). High energy fodder and protein ration may be added to the halophytic feed for improving its quality (Attia-Ismail, 2003). Suitable agronomic interventions may be explored as quicker and easier approach to improving the yield, quality and palatability of these feeds.

Concentrate (energy ration) is an important component of the animal diet which is meant for fattening. Its significance was highlighted in trial 1 and 2 . Whereas in Trial 1, wheat bran which is $17-20 \%$ of the concentrate (Table 2) was present in diet 1 and compensated growth to some extent but animals feeding on diets 2, 3, 4 having full energy ration (concentrate as well as extra wheat bran) showed better growth (Fig. 1A, Table 4). The absence of full concentrate from diet 1 appeared responsible for this response. On the other hand although protein-rich Berseem (Table 3) was present in diet of trial 2 (Table 2), the total absence of energy ration here resulted in sustenance of growth for only a short period after which there was weight loss which was restored only after adding concentrates to the diet (Fig. 1B, Table 4). However, because of being costly, there is a need to use the concentrate judiciously, preferably during the last month of a fattening regime, but further experiments are needed for elaboration. While generating knowledge on the potential use of halophytes as green/dry fodder may be beneficial, finding suitable halophytic ingredients for the energy ration will be of further benefit. This would not only help in meeting the chronic shortage of these commodities and lower the cost of production but will also impact on conservation and management of saline environments. This has far reaching consequences taking into consideration the ever increasing human population and decreasing agricultural productivity. Therefore, we targeted replacement of conventional concentrate sources (cotton seed cake and molasses) with halophytic components ( $P$. juliflora pods and $M$. zapota fruit) and found that there was no significant difference in weight gain of animals feeding either diet but protein content was better in meat of animals fed diet having concentrate with halophytic components (Fig. 1D, Table 4).

In any case, it may not be advisable to raise animals solely on halophytic ration due to likely health hazards (El Shaer, 2010). This is especially true in long term use like feeding cows kept for milk. Before recommending such a practice, there is a need to conduct extensive feeding trials to formulate a suitable combination of halophytes and traditional non halophytes, which when fed to animals would have no/minimum ill effects on their health and simultaneously produce good quality meat/milk (Gul et al., 2014). In the present study, the use of halophytic resources has been explored in feed of animals raised for meat. These animals are slaughtered after feeding for 3-4 months and no adverse effect was noted on their health and/or growth during this period. Here, certain formulations with halophytes rather helped in equal or more weight gains than conventional rations (El Shaer, 2005).

In conclusion, $P$. antidotale appears an alternate source of green and dry fodder in the replacement of maize and wheat straw, respectively. Whereas, D. bipinnata may be a good replacement of wheat straw as a dry fodder when used in combination with green maize. Halophytic species of this study are successfully replacing the conventional cattle feed as green/hay/concentrate to improve calves weight and quality of meat. These findings may be applicable under similar environmental conditions elsewhere like the region from Rajasthan in India to Morocco including Pakistan, countries of the Middle East and North and Central Africa. More elaborate trials are needed to find optimum combinations of the grass species used in this study and find some other suitable candidates to meet dry/green fodder requirement and explore the possibility of improving the palatability and acceptability of such grasses.

Acknowledgements: Financial support from the Ministry of Science and Technology, Higher Education Commission and Pakistan Academy of Science is gratefully acknowledged. We are thankful to M/s. S. Zia-ul-Haq and Sons, especially their Manager, General Services- Mr. Zakir Abowath for help in conducting animal trials and other activities at their field stations at Hub Kund, Baluchistan and Gadap, Karachi. We thank Dr. A. Larbi, ICARDA, Syria, for critical comments on the manuscript.

\section{REFERENCES}

Ahmed, R. and K.A. Malik. 2002. Prospects of Saline Agriculture. Kluwer Academic Press, Netherlands.

Al-Ahmadi, M.J. and M. Kafi. 2008. Kochia (Kochia scoparia): To be or not to be. pp.119-142. In: M. Kafi and M.A. Khan (ed.), Crop and Forage Production using Saline Waters. NAM S\&T Centre, Daya Publisher, New Delhi, India.

Ali, H., B. Gul, M.Y. Adnan, M.Z. Ahmed, I. Aziz, S. Gulzar and M.A. Khan. 2014. NPK mediated improvement in biomass production, photosynthesis and $\mathrm{Na}^{+}$regulation in Panicum antidotale under saline conditions. Pak. J. Bot. 46:1975-1979.

Allah, S.U., A.A. Khan, A. Burkert and M. Wachendorf. 2014. Socio-economic aspects of fodder production in urban and peri-urban of Faisalabad. Pak. J. Agri. Sci. 51:483490.

AOAC. 2005. AOAC, Official methods of analysis, $16^{\text {th }} \mathrm{Ed}$. Association of Official Analytical Chemists, Washington, DC.

Attia-Ismail, S.A. 2003. Metabolism and nitrogen balance in the rumen of sheep under the influence of drinking saline water and flavomycin. Egyptian J. Nutr. Feeds 6:11431152. 
Badri, M.A. and A.I. Hamed. 2000. Nutrient value of plants in an extremely arid environment (Wadi Allaqi biosphere reserve, Egypt). J. Arid Environ. 44:347-356.

Cope, T.A. 1982. Poaceae. In: E. Nasir and S.I. Ali (ed.), Flora of Pakistan. University of Karachi, Pakistan.

El Shaer, H.M., F.T. Ali, Y.S. Nadia, S. Morcos, S.S. Emam and A.M. Essawy. 2005. Seasonal changes of some halophytic shrubs and the effect of processing treatments on their utilization by sheep under desert conditions of Egypt. Egyptian J. Nutr. Feeds 8:417-431.

El Shaer, H.M. 2010. Halophytes and salt-tolerant plants as potential forage for ruminants in the Near East region. Small Ruminant Res. 91:3-12.

Gul, B., R. Ansari, H. Ali, M.Y. Adnan, D.J. Weber, B.L. Nielsen and M.A. Khan 2014. The sustainable utilization of saline resources for livestock feed production in arid and semi-arid regions: A model from Pakistan. Emir. J. Food Agric. 26:1032.

Gulzar, S., M.A. Khan and L. Xiaojing. 2007. Seed germination strategies of Desmostachya bipinnata: a fodder crop for saline soils. Rangeland Ecol. Manag. 60:401-407.

Iqbal, M. and M. Ahmad. 2005. Science \& Technology based Agriculture vision of Pakistan and prospects of growth. pp.10-12. Proceedings of the $20^{\text {th }}$ Annual General Meeting Pakistan Society of Development Economics, Islamabad, Pakistan.

Khan, A.F. 2011. Developing quality livestock. Economic and Business Review, Daily DAWN; p.III, January 24-30.
Khan, M.A. and M. Qaiser. 2006. Halophytes of Pakistan: Distribution, Ecology, and Economic Importance. pp.129-153. In: M.A. Khan, H. Barth, G.C. Kust and B. Boer (eds.), Sabkha Ecosystems: The South and Central Asian Countries, Vol. II. Springer, Netherlands.

Khan, M.A., R. Ansari, H. Ali, B. Gul and B.L. Nielsen. 2009. Panicum turgidum, a potentially sustainable cattle feed alternative to maize for saline areas. Agri. Ecosys. Env. 129:542-546.

Koyro, H.-W., T. Hussain, B. Huchzermeyer and M.A. Khan. 2013. Photosynthetic and growth responses of a perennial halophytic grass Panicum turgidum to increasing $\mathrm{NaCl}$ concentrations. Environ. Exp. Bot. 91:22-29.

Le Houerou, H.N. 1992. The role of salt bushes (Atriplex sp.) in arid land rehabilitation in the Mediterranean basin: a review. Agroforest. Syst. 18:107-147.

Lieth, H. and A.A. Masoom. 1993. Towards the Rational Use of High Salinity Tolerant Plants: Agriculture and forestry under marginal soil water conditions, Vol. 2. Proceedings of the First ASWAS Conference December 8-15, 1990 at the United Arab Emirates University Al Ain, United Arab Emirates.

Norman, H.C., D.G. Masters and E.G. Barrett-Lennard. 2013. Halophytes as forages in saline landscapes: interactions between plant genotype and environment change their feeding value to ruminants. Environ. Exp. Bot. 92:96109.

SPSS. 2001. SPSS for Windows (Release 11) (Chicago: SPSS). 